\title{
THE BOOK OF TASTY AND HEALTHY FOOD: MYTHOLOGY OR PRAGMATICS?*
}

\author{
Svetana Yurlova \\ Ural Federal University, \\ Yekaterinburg, Russia
}

This article is devoted to an iconic but little-studied phenomenon of Soviet life, The Book of Tasty and Healthy Food. The most studied aspect of this work is the ideological one: however, this paper considers a completely different dimension. The main objective of the proposed analysis is to detect the dialectic of the mythological and the pragmatic in the text and structure of this book. All myths (and modern ones are no exception) do not simply form a picture of the world: they also regulate and direct the practices of everyday life. Using this specific text, the article examines the formation of new practices of everyday Soviet life. The author relies both on synchronic and diachronic analysis, as it is important not only to understand how the text of The Book of Tasty and Healthy Food was structured, but also to trace the transformation that occurred from edition to edition. The book was reprinted many times; this study focuses on four editions $(1939,1952,1955)$. The article shows the practical significance of the book and how it reflects the real changes in the lives of Soviet citizens.

Keywords: culture of everyday life; Soviet culture; utopian project; gastronomical culture; mythology; ideology; pragmatics.

Рассмотрен знаковый, но малоисследованный феномен советской повседневности - «Книга о вкусной и здоровой пище». Наиболее изученный аспект данного издания - идеологический, однако в представленной работе предложен совершенно иной ракурс ее рассмотрения. Главной задачей автора является обнаружение диалектики мифологического и прагматического в тексте и структуре книги. Любой миф (и современный не исключение) не просто формирует картину мира, а регламентирует и направляет практики повседневности. В статье на конкретном материале анализируется процесс формирования новых практик повседневности советского человека. Автор опирается на единство синхронического и диахронического аспектов исследования материала, поскольку важно не только понять, как изначально была сформирована структура текста, но и проследить транс-

* Citation: Yurlova, S. (2019). The Book of Tasty and Healthy Food: Mythology or Pragmatics? In Quaestio Rossica. Vol. 7, № 3. P. 751-760. DOI 10.15826/qr.2019.3.405.

Цитирование: Yurlova S. The Book of Tasty and Healthy Food: Mythology or Pragmatics? // Quaestio Rossica. Vol. 7. 2019. № 3. P. 751-760. DOI 10.15826/qr.2019.3.405.

(C) Yurlova S., 2019

Quaestio Rossica • Vol. 7 • 2019 • № 3, p. 751-760 
формации, происходившие от издания к изданию. Книга переиздавалась множество раз, однако для строгости исследования в контексте советской культуры были выбраны четыре издания - 1939, 1952 и 1955 гг. Показаны практическая значимость «Книги о вкусной и здоровой пище» и отражение в ней реальных изменений домашнего быта советского человека.

Ключевые слова: культура повседневности; советская культура; утопический проект; гастрономическая культура; мифология; идеология; прагматика.

Soviet culture has a special place in philosophical and cultural studies, attracting both Russian and Western scholars. In a sense, we are experiencing a renaissance of Soviet culture, revealing itself either as an advertising image, the revival of Soviet brands, or, of course, in the great number of profound studies dealing with Soviet culture [Глущенко; Кагарлицкий; Куренной; Утехин; Basile]. The paradox, as far as the analysis of Soviet cultural diversity is concerned, lies in the fact that most researchers are simultaneously inside and beyond their subject. Many know the Soviet past as part of their personal history, with memory feeding them hands-on material derived from experience and not abstract knowledge. On the other hand, the time gap and, more importantly, the change in ideological paradigm allow them to maintain a scholarly attitude when "dissecting" their own past.

For quite a long time, the scope of my interests has included the phenomenon of the contemporary myth, or rather the mythological component of human consciousness in the $20^{\text {th }}$ and $21^{\text {st }}$ centuries. As I wrote in one of my previous articles: "There is a basic difference between a contemporary myth and an archaic one, namely, the former does not forbid or approve of individuals' behaviour. It rather tends to manipulate their minds. This fact explains the binarity of the contemporary myth-making process: on the one hand, myths are purposefully modelled by ideologists in power; on the other hand, they are supported and promoted by people" [Юрлова, с. 65].

One of the most powerful forms of the mythological paradigm of consciousness in the $20^{\text {th }}$ century was totalitarian mythology. Despite the differences in the national traditions of the countries where totalitarian ideology became the basis for the political and state structure (Germany, Italy, Spain, the Soviet Union), the mythological paradigm of totalitarian consciousness is universal. It is important to note that totalitarian mythology, as a rule, is present not so much in ideological maxims as in the form of the stable mythologemes of mass consciousness. The practice of everyday life, implementing these mythologemes, supports and develops a certain view of the world generated by totalitarian ideology.

There is no doubt that the Soviet myth was one of the most remarkable phenomena in that period's culture. A specific feature of the Soviet myth is that it developed in a holistic utopian project, which not only modelled the imminent onset of communism but also regulated the actual implementation of social utopia in everyday life. Equally, the story of the birth of a new world itself forms a special mythological space, creating new heroes/demiurges 
and including real historical events into a global utopian project. As mentioned above, strong mythologems of mass consciousness take hold in the actual practice of everyday life. From this point of view, Soviet culture formed a number of powerful tools to implement elements of global utopia in the life of the people. Primacy definitely belongs to the media and the arts. Lacking the opportunity to consider this issue in detail, we shall just note a number of recent works where the problem is analyzed on the basis of specific historical material [Алексеев, Бурденков; Ефремова]. An effective tool for this kind of "formatting" of everyday life in the 1930s was constructivist architecture and new principles for organizing public space [Вронская].

The object of my research in this article is The Book of Tasty and Healthy Food as a landmark event in Soviet everyday life. The choice of this material was urged by a mere idea: that this book is an embodiment of the Soviet myth that 'life has become better, life has become merrier'. My childhood memory of this extraordinary edition is that of a 'picture book', where everything was unlike reality. That is why when I began to become interested in this book, I considered mythology, which permeates the text and illustrations, as its principal characteristic. It reminded me of the famous Soviet film Кубанские казаки (Kuban Cossacks) by I. Pyriev (ardently criticized in the 1990s as a sample of the falsity of Soviet cinema in the Stalin period): it offers the same image of abundance and optimism in the life of a Soviet man. From this perspective, The Book of Tasty and Healthy Food was one of the most important tools for introducing the Soviet utopia into everyday life.

A certain amount of research already features The Book of Tasty and Healthy Food prominently [Добренко; Сохань] would like to mention I. Glushchenko's Public Catering. Mikoyan and Soviet Cuisine [Глущенко]. The author investigates Soviet cuisine in terms of both the ideological and personal aspects of its formation. In particular, attention is focused on the role of A. Mikoyan in the development and promotion of this new way of life. Glushchenko especially emphasizes The Book of Tasty and Healthy Food, as its initiator and inspiration was Mikoyan, at that time People's Commissar for the Food Industry of the USSR. However, the author studies much wider material than this publication and the research perspective is different.

We deliberately do not touch the ideological component of the text because there can be no doubting its existence. The main objective of the proposed analysis is to reveal the dialectics of the mythological and the pragmatic in the text and structure of the book. All myths (including modern ones) not only shape a person's world view but also regulate and direct the practice of everyday life. Let us try to see how this happens in a particular text. To make the study complete, we seek to combine synchronic and diachronic aspects because it is important to not only understand how the structure of The Book of Tasty and Healthy Food was originally formed but also to trace its transformation from edition to edition. The book was reprinted many times, but four editions (1939, 1952, 1955 and 1962) have been selected for this essay. The reason for this choice is as follows. From 1939 to 1962 , Soviet society underwent several crucial stages - from the 
totalitarian model to the Khrushchev Thaw. In addition, the 1939 edition was the first and therefore the most important, while the book published in 1952 is recognized as the reference version of the text.

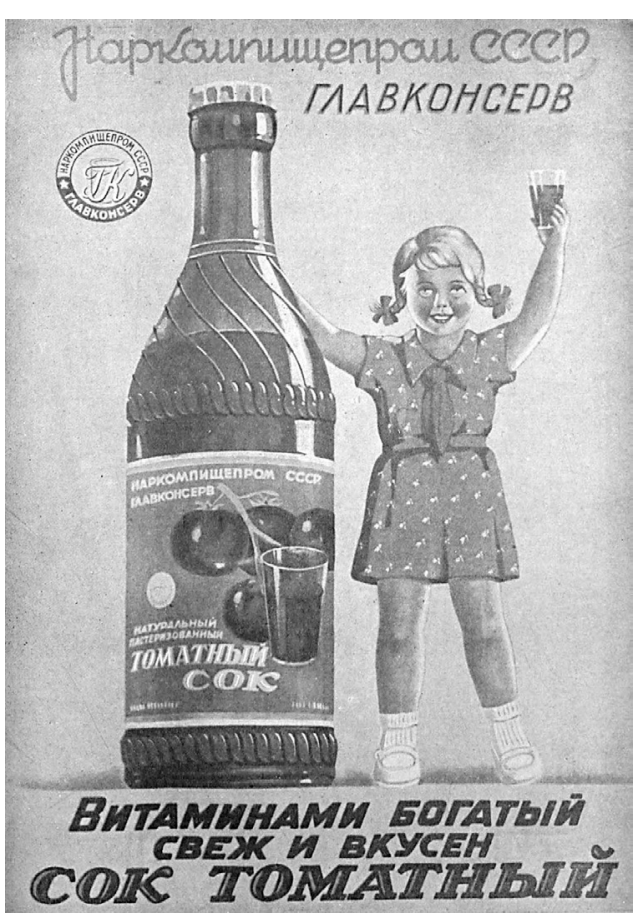

1. Tomato juice advertisement // Книга о вкусной и здоровой пище. М., 1939

The synchronic aspect of research requires taking into account the peculiarities of the text's external structure. This structure has three main components: 1) chapters devoted to the food culture in general, 2) recipes, and 3) marginalia. In our opinion, marginalia are of special interest because it is there that we can see the paradox of culinary discourse. However, this aspect of the study requires separate consideration and will be explained in another article.

The mythological component of the book consists of three main areas. The first is a basic myth of universal abundance (using traditional terms - the "Golden Age" mythologeme). It is important to note that the image of the "Golden Age" depends on the year of publication. For instance, the 1939 edition contains a message to the future, the forthcoming achievements of Soviet society. The preface to the first edition reads:

The Bolshevik rate of developing the Soviet food industry brings us closer to a time when socialism will demonstrate to the world an example of unprecedented abundance of food. An abundance of highly nutritious, varied, and tasty food, the best in the world! An abundance which will completely solve nutrition problems and create all the facilities for the education of healthy, strong, and eternally youthful people [Книга о вкусной и здоровой пище, 1939, с. 11] ${ }^{1}$.

The following editions report on progress in the development of the food industry and the growth of employee welfare. "Our flourishing Motherland, pacing at the forefront of progressive mankind in the fight for peace and security for all peoples, is becoming more and more beautiful and

\footnotetext{
1 The texts of all Russian-language publications are translated by I. Novikova.
} 
richer with each passing day... Socialism liberated our people from the wolf laws of capitalism, hunger, poverty, and chronic malnutrition, from the need to adapt their needs and tastes to the primitive choice of food" [Книга о вкусной и здоровой пище, 1955, с. 16]. The myth about achieved abundance was certainly contradicted by real life at that time, but it is worth noting that certain changes in the food culture of Soviet citizens did take place. The first edition clearly accentuates the emergence of the industrial production of food and partially prepared products. Gluschenko writes: "The food industry of the Soviet country was the result of successful industrialization. It was not just new technologies and new labour relations, but, in general, something that the old Russia did not know." [Глущенко, с. 144].

The food industry's finished products play an important role in all editions of the book. And here we can trace an interesting trend. The 1939 edition is replete with descriptions and illustrations, not so much of the food products themselves as of food enterprises and technology. Thus, the introduction to this edition (entitled "Forwards to Socialist Abundance") is, in fact, entirely devoted to describing the food industry and the introduction of new technologies, which is not the case in the later editions $(1952,1955,1962)$. Someone who has never seen the 1939 edition will be surprised to see adverts for bouillon cubes, crackers, canned soups, cereals, etc. We will return to the issue of advertised food products. In the meantime, we would like to note that the focus shifts gradually from food production to food consumption with every reprint of the book.

The second most important myth structuring the content of The Book of Tasty and Healthy Food deals with the liberation of women from domestic slavery. This particular component determines a number of structural elements. The idea of liberation from domestic chores permeates materials on the development of the food industry as well. The intention to give practical effect to this idea underpins the diversity of ads contained in the text. Moreover, following the principle of diachronic consideration, we find a growing variety of end products advertised - from the aforementioned bouillon cubes in 1939 to sausages and cereals (kisel, puddings, etc. $)^{2}$ in 1955. Let us consider this myth in more detail.

A special chapter devoted to the kitchen chores of Soviet women appears in the 1952 edition for the first time. Entitled Kitchen, it contains several sections: kitchen space, food stock and storage, stove and heating appliances, and kitchenware. However, this is not the only place in the text where technologies facilitating kitchen chores are promoted. Almost every section provides a detailed description of the use of new kitchen utensils and heating appliances. For instance, in the 1952 edition, the section Dough Products offers detailed illustrated instructions on the use of a device called a "chudo-pan" ("miracle pan"). It is fair to say that this device continues to be successfully used by modern housewives. However, if we read the instructions from 1952 carefully, we can see that this device was intended

${ }^{2}$ Kisel refers to a fruit dish that uses a variety of starches to give it considerable viscosity. 
ПЕЧЬ-КАСТРЮЛЯ „ЧУДО

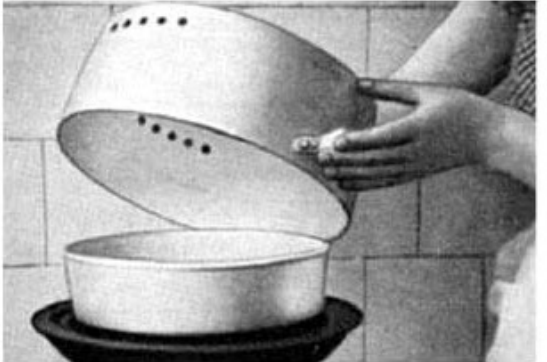

Подставка, форма и крышка к ией

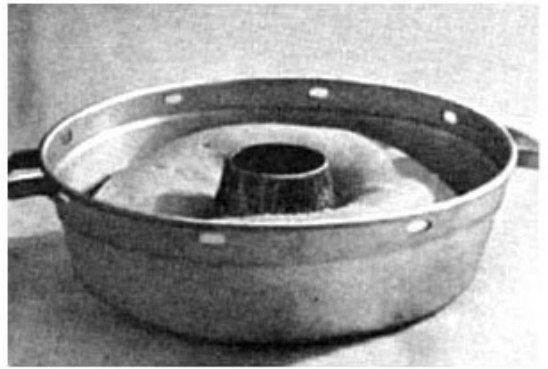

Дрожмевое тесто надо класть до половины высоты формы

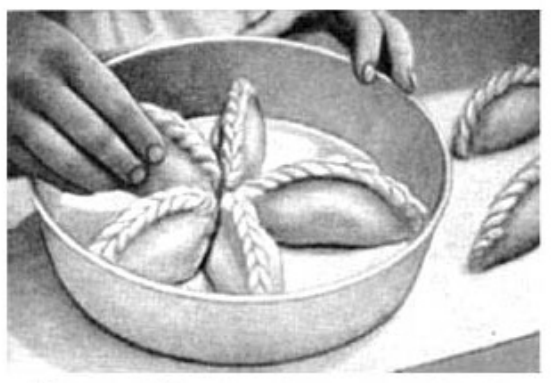

В печи жчудо» можно выпекать пирожки

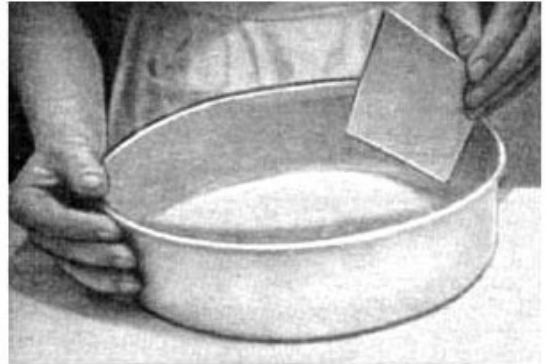

Можсно выпечь бисквит, застлав бока и дно печи бумагой

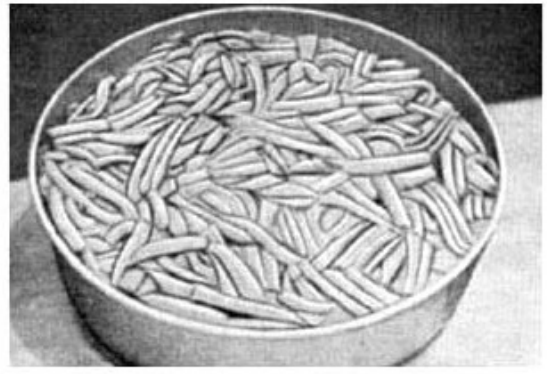

Можно приготовить в печи «чудо» макаронную запеканку

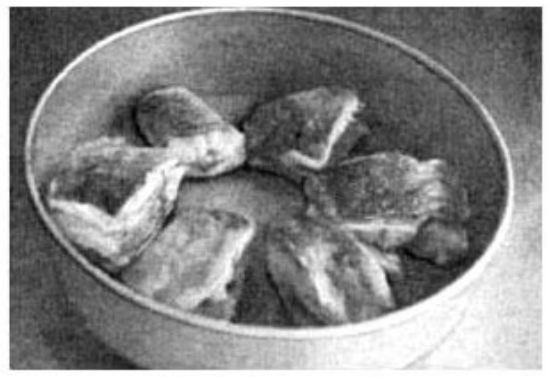

Можно запечь рыбу

2. Miracle pan // Книга о вкусной и здоровой пище. М., 1955

to be used on a primus stove, kerosene stove, or gas burner [Книга о вкусной и здоровой пище, 1952, с. 301-302].

Changes in this area of home cooking include primarily the promotion of partially prepared food and not the introduction of new appliances. 
In addition, it is the recommendation to use new appliances that is the most utopian here. For example, a refrigerating cabinet (described in the section Kitchen of the 1952 edition), was either not actually available or was reserved as a luxury item for the political elite.

At first glance, this aspect of the text is the most pragmatic (freedom from time-consuming cooking through the use of partially prepared food and mechanical 'assistants'). However, this harmonious and beautiful world of the Soviet kitchen is destroyed when one reads the recommendations for a healthy and well-balanced diet. In all editions, from 1939 to 1962, the chapter entitled The Procedure of Cooking Lunch reads:

Take, for example, a three-course meal with an appetizer (herring with a side dish): the first course - meat-and-cabbage soup, the second course chopped meat and fried potatoes, the third course - kisel. You should start with the preparation of the meat and cooking a broth. Rinse the meat, put it on a cutting board, cut some flesh for chops and set them aside in a bow; put the rest of the meat and bones for the broth into a pot, pour cold water to cover the meat and place it on a stove. Meanwhile, you can clean and cut a pre-soaked herring and put it on a tray, shaping it into the form of a whole fish. Boil some potatoes... While the kisel is cooking, the broth will start to boil. Skim off the froth and reduce the heat. Now it's time to take care of the roots, onions, and cabbage for the soup - clean, wash and cut them, and roast some roots and onions. By this time, the broth will almost be ready; strain it into the soup pot, put the meat in, add the cabbage, roasted roots, salt, pepper, and bay leaf, and continue cooking. While the soup is simmering, mince the meat and make chops, roll them in bread crumbs... Peel the boiled potatoes, cut them, and fry in a pan... use another pan and start frying the chops. $<\ldots>$ Remove the meat from the soup, cut it into small pieces, put it onto plates, pour soup, add some sour cream, and sprinkle with parsley or dill. Put the cooked chops and the side dish (fried potatoes) on a platter... sprinkle the potatoes with parsley or dill [Книга о вкусной и здоровой пище, 1952, с. 27-28].

The description is complemented with marginalia giving recommendations for lunch menus in different seasons [Там же, с. 43-52]. Such recommendations were purely utopian and could not be realized in actual household practice. ${ }^{3}$

The third component is the mythology of the new way of life. Of all the analyzed aspects, this myth is, perhaps, the most coherent and, at the same time, the most paradoxical. In the framework of the text, the mythology of the new way of life is presented in two points.

${ }^{3}$ Allow me to remind you of a well-known dialogue from the novel The Master and Margarita by M. Bulgakov: «Слуга покорный, - трубил Амвросий, - представляю себе твою жену, пытающуюся соорудить в кастрюльке в общей кухне дома порционные судачки а натюрель!..» ("Thanks a million", boomed Amvrosy, "I can imagine your wife trying to cook perch au naturel in a saucepan in the communal at home!") [Булгаков, c. 323]. 
The first is food culture. The book aims to create new standards of food culture, meaning the introduction of a healthy diet and urban living standards into everyday practice. This is most clearly seen in the sections dealing with health and safety standards. From the very first edition, an important place in the book is given to the sections The Importance of a Balanced Diet for Human Development, Dietetic Therapy, and Baby Food. The 1952 edition was the first to introduce a new section, Nutrition during Pregnancy and Breastfeeding. However, this aspect is not very significant in the context of this article.

Let us now turn to the etiquette component of the recommendations. A detailed study of the section Table Layout shows a picture of a classic meal typical of a wealthy citizen in pre-revolutionary Russia. Without going into detail, we point out the presence of elements such as dessert plates, a serving table, napkins, etc. From edition to edition, this section gets broader. The daily life of a Soviet citizen of the time (both in 1939 and in 1962) would hardly suggest such a table layout, especially since the meals being discussed are normal family lunches as well those for festive occasions. However, the mythology of the new way of life sought to form the image of a prosperous, aesthetically pleasing, and cultural (in the common meaning of this notion) Soviet family life. Here is a most demonstrative quote: "Place the napkins, folded as a triangle or a cap, on a snack plate. A home lunch usually does notsuggest a choice of wine [my emphasis]. Therefore, there is no need to put extra glasses on the table. If you have a dinner party, serve a shot glass for vodka, a glass for wine, and tall glasses for mineral water and fruit and tomato juice next to each table place" [Книга о вкусной и здоровой пище,1952, с. 29-30].

This extract is important not only in relation to the formation of a mythologized image of everyday Soviet life. What is much more important is that the image of wealth and material well-being created in Soviet culture is permeated with the bourgeois, and in no case refers to proletarian simplicity and unpretentiousness. On the contrary, the concept of high food culture was something that would have been called philistinism in the 1920s. However, there is another tendency, namely the profanation of high cuisine. This primarily relates to ingredients - sophisticated, exotic, and overly "bourgeois" components are replaced by the simple and obvious ones. A comparative analysis of the editions of 1939 and 1952 reveals that the latter lacked the recipes for complex dishes with exclusive ingredients contained in the former (fish telnoye, deep fried fish, catfish with apples) [Книга о вкусной и здоровой пище, 1939, с. 88-90], and beef with oranges [Там же, c. 116]. You will also not find croutons, canapés, endive, or romaine lettuce in the 1952 edition [Книга о вкусной и здоровой пище, 1952, с. 295, 33]. There is diffusion of old and new, which results in the formation of an image of Soviet abundance.

The Book of Tasty and Healthy Food provides rich material for researchers; of course, we are not able to consider all aspects of this iconic text in one article. Thus, there are problems such as the national component, 
the peculiarities of presenting pre-revolutionary gastronomic culture, and many other points that are beyond our study.

In conclusion, it should be noted that this analysis leads to several important findings. First, the mythological component of The Book of Tasty and Healthy Food was definitely an important part of the Soviet myth of an ideal society. It was one of the components of a global utopian project implemented in all parts of Soviet culture - from constructivist architecture to films depicting the image of a "golden age" to come.

Secondly, the practical importance and real reflection of changes in the Soviet household is an integral aspect of the book. The most important period in this respect is the 1950s.

Third, it is paradoxical that it was not the popular culinary tradition (as would be logical in the context of communist ideology) but the gastronomic culture of wealthy citizens that functioned as the model for the new life of the Soviet citizen, a historical reference to middle-class culture.

\section{Список литературы}

Алексеев E., Бурденков E. «Иконография» Товарища Андрея (Якова Свердлова) и механизм советского мифотворчества // Quaestio Rossica. T. 4. 2016. № 2. C. 45-79. DOI 10.15826/qr.2016.2.158.

Булгаков М. Мастер и Маргарита. Минск : Юнацтва, 1988. 670 с.

Глущенко И. Общепит. Микоян и советская кухня. М. : Изд. дом Высш. шк. экономики, 2015. $239 \mathrm{c}$.

Добренко E. Гастрономический коммунизм: вкусное vs. здоровое // Неприкосновенный запас. 2009. № 2 (64). С. 155-173.

Ефремова E. «Здесь будет город-сад»: утопический образ города в заводской газете Уралмаша // Quaestio Rossica. 2015. № 4. C. 57-82. DOI 10.15826/qr.2015.4.126.

Книга о вкусной и здоровой пище / под ред. Б. В. Виленкина, О. П. Молчанова. М. : Пищепромиздат, 1939. 435 с.

Книга о вкусной и здоровой пище / под ред. О. П. Молчанова, Д. И. Лобанова. М. : Пищепромиздат, 1952. 454 с.

Книга о вкусной и здоровой пище / под ред. О. П. Молчанова, Д. И. Лобанова. М. : Пищепромиздат, 1955.400 с.

СССР : жизнь после смерти / под ред. И. Глущенко, Б. Кагарлицкого, В. Куренного. М. : Изд. дом Высш. шк. экономики, 2012. 157 с.

Сохань И. В. «Книга о вкусной и здоровой пище»: гастрономические образы сталинской эпохи // Человек. 2012. № 6. С. 139-153.

Утехин И. Очерки коммунального быта. М. : ОГИ, 2001. 248 с.

Юрлова С. Мифологема Москвы в культуре сталинской эпохи // Изв. Урал. гос. ун-та. Сер. 2, Гуманитарные науки. 2008. Вып. 15. № 55. С. 64-70.

Basile G. M. The Algebra of Happiness: Yevgeniy Zamyatin's We // Quaestio Rossica. 2015. № 4. P. 19-39. DOI 10.15826/qr.2015.4.124.

Vronskaya A. The Utopia of Personality: Moisei Ginzburg's Project for the Moscow Park of Culture and Leisure // Quaestio Rossica. 2015. № 4. P. 40-56. DOI 10.15826/ qr.2015.4.125.

\section{References}

Alekseev, E., Burdenkov, E. (2016). "Ikonografiya" Tovarishcha Andreya (Yakova Sverdlova) i mekhanizm sovetskogo mifotvorchestva [The Iconography of Comrade 
Andrei (Yakov Sverdlov): A Mechanism of Soviet Mythmaking]. In Quaestio Rossica. Vol. 4. No. 2, pp. 45-79. DOI 10.15826/qr.2016.2.158.

Basile, G. M. (2015). The Algebra of Happiness: Yevgeniy Zamyatin's We. In Quaestio Rossica. No. 4, pp. 19-39. DOI 10.15826/qr.2015.4.124.

Bulgakov, M. (1988). Master i Margarita [The Master and Margarita]. Minsk, Yunatstva. $670 \mathrm{p}$.

Dobrenko, E. (2009). Gastronomicheskii kommunizm: vkusnoe vs. zdorovoe [Gastronomic Communism: Tasty vs. Healthy]. In Neprikosnovennyi zapas. No. 2 (64), pp. 155-173.

Efremova, E. (2015). “Zdes' budet gorod-sad": utopicheskii obraz goroda v zavodskoi gazete Uralmasha [Here will be a Garden-city: Utopian Image of a City in the Uralmash Plant Newspaper]. In Quaestio Rossica. No. 4. pp. 57-82. DOI 10.15826/qr.2015.4.126

Glushchenko, I. (2010). Obshchepit. Mikoyan i sovetskaya kukhnya [Public Catering. Mikoyan and Soviet Cuisine]. Moscow, Izdatel'skii dom Vysshei shkoly ekonomiki. 239 p.

Glushchenko, I., Kagarlitskii, B, Kurennoi, V. (2012). SSSR: zhizn'posle smerti [USSR: Life after Death]. Moscow, Izdatel'skii dom Vysshei shkoly ekonomiki. 157 p.

Molchanov, O. P., Lobanov, D. I. (1952). Kniga o vkusnoi i zdorovoi pishche [The Book of Tasty and Healthy Food]. Moscow, Pishchepromizdat. 454 p.

Molchanov, O. P., Lobanov, D. I. (1955). Kniga o vkusnoi i zdorovoi pishche [The Book of Tasty and Healthy Food]. Moscow, Pishchepromizdat. 400 p.

Sokhan', I. V. (2012). "Kniga o vkusnoi i zdorovoi pishche”: gastronomicheskie obrazy stalinskoi epokhi [The Book of Tasty and Healthy Food: Gastronomic Images of the Stalin Era]. In Chelovek. No. 6. pp. 139-153.

Utekhin, I. (2001). Ocherki kommunal'nogo byta [Essays on Communal Life]. Moscow, Ob"edinennoe gumanitarnoe izdatel'stvo. 248 p.

Vilenkin, B. V., Molchanov, O. P. (1939). Kniga o vkusnoi $i$ zdorovoi pishche [The Book of Tasty and Healthy Food]. Moscow, Pishchepromizdat. 435 p.

Vronskaya, A. (2015). The Utopia of Personality: Moisei Ginzburg's Project for the Moscow Park of Culture and Leisure. In Quaestio Rossica. No. 4, pp. 40-56. DOI 10.15826/qr.2015.4.125.

Yurlova, S. (2008). Mifologema Moskvy v kul'ture stalinskoi epokhi [The Mythology of Moscow in the Culture of the Stalin Era]. In Izvestiya Ural'skogo gosudarstvennogo universiteta. Seriya 2, Gumanitarnye nauki. Iss. 15. No. 55, pp. 64-70. 


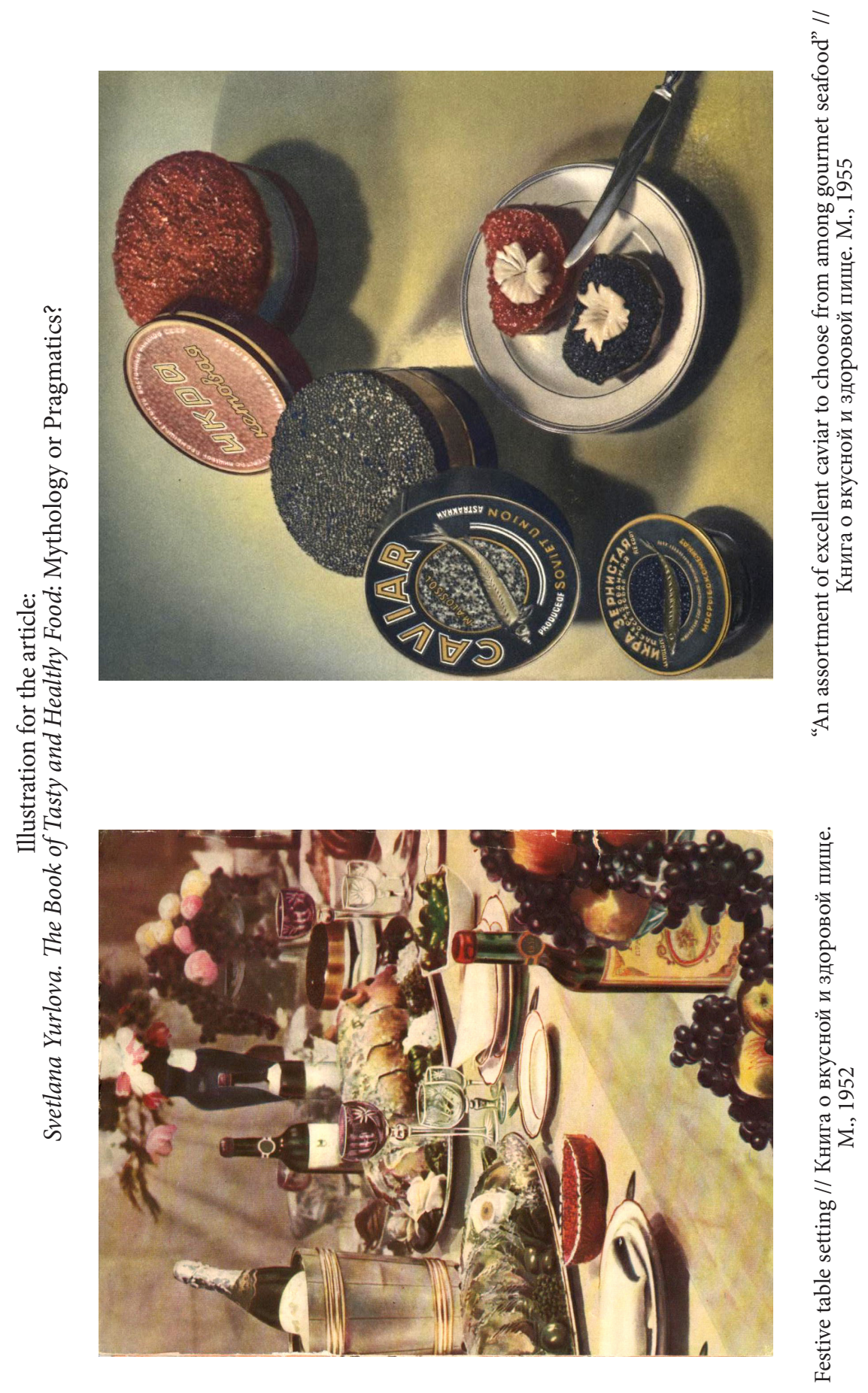



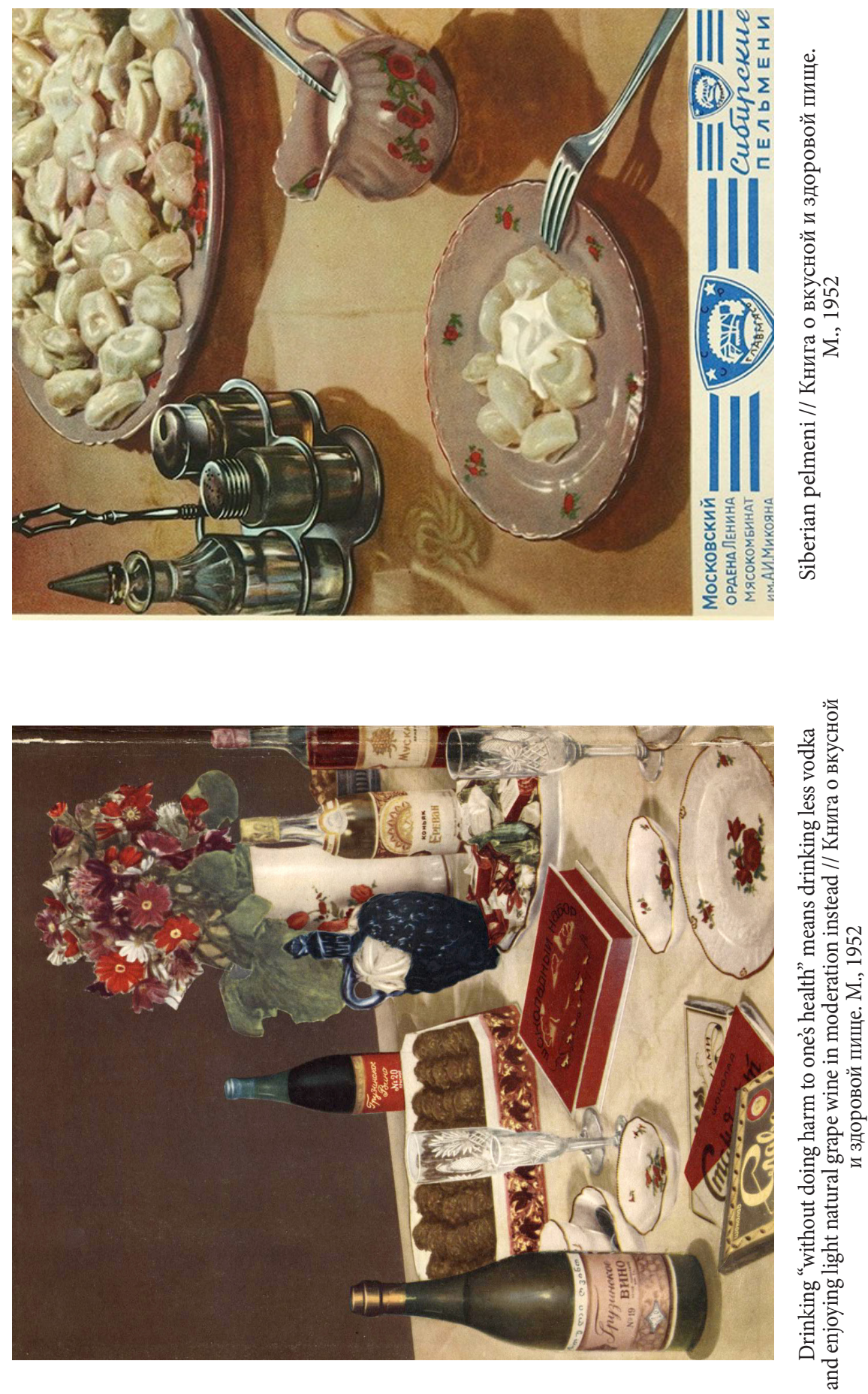